điều trị bằng insulin, tỷ lệ cao nhất ở nhóm III với $62,5 \%$, các bệnh nhân được điều trị bằng $S U$ gặp ít hơn $(18,1 \%)$. Kết quả này của chúng tôi phù hợp với nghiên cứu củaBingyan $\mathrm{CaO}^{3}$ và Ewan R. Pearson ${ }^{5}$. Điều này xảy ra do đặc thù trẻ nhỏ, nhạy cảm với insulin và đường máu dao động bởi chế độ ăn thường xuyên của trẻ.

Trong nghiển cứu của S.E Flanagan có tới 14\% bệnh nhân ĐTĐSS do bất thường 6 q24 có biểu hiện hạ glucose máu sau khi dừng thuốc ${ }^{8}$. Tuy nhiên 6 bệnh nhân bất thường 6q24 trong nghiên cứu của chúng tôi không có trường hợp nào xuất hiện cơn hạ glucose máu trong thời gian theo dõi cũng như không phải tái sử dụng thuốc trong những đợt stress bởi nhiễm trùng.

\section{KẾT LUÂN}

KSGM đạt mục tiêu ở 94,1\% bệnh nhân có đột biến $A B C C 8 / K C N J 11$ khi điều trị với SU (dựa vào glucose máu và $\mathrm{HbA1c}$ ); ở các bệnh nhẩn mang đột biến khác là $37,5 \%$ (dựa vào HbA1c), $25 \%$ (dựa vào glucose máu); các bệnh nhân không có đột biến là $71,4 \%$ (dựa vào $\mathrm{HbA1c}$ và glucose máu). $100 \%$ bệnh nhân có bất thường 6q24 được KSGM tốt trước khi dừng thuốc, chưa có bênh nhân nào tái phát. 2/7 bệnh nhân không có đột biến gen đã được dừng thuốc nhưng phải tái sử dụng insulin trong những đợt nhiễm trùng cấp tính; 1 bệnh nhân chưa phát hiện đột biến điều trị bằng SU có mức KSGM ban đầu tốt, khi chuyển đổi sang insulin có mức glucose máu tốt nhưng HbA1c kém. Không có bệnh nhân hạ glucose máu nặng, hạ glucose máu không triệu chứng gặp chủ yếu ở nhóm điều trị bằng insulin.
Cần chỉ định phân tích gen cho trẻ mắc đái tháo đường trong vòng 12 tháng đầu sau đẻ để lựa chọn phương pháp điều trị thích hợp.

\section{TÀI LIÊU THAM KHẢO}

1. Dahl A, Kumar S. Recent Advances in Neonatal Diabetes. Diabetes Metab Syndr Obes. 2020;13:355-364. doi:10.2147/DMSO.S198932

2. Rewers MJ, Pillay $K$, de Beaufort $C$, et al. ISPAD Clinical Practice Consensus Guidelines 2014. Assessment and monitoring of glycemic control in children and adolescents with diabetes. Pediatr Diabetes. 2014;15 Suppl 20:102-114. doi:10.1111/pedi.12190

3. Cao B, Gong $C_{\text {, }}$ Wu D, et al. Genetic Analysis and Follow-Up of 25 Neonatal Diabetes Mellitus Patients in China. J Diabetes Res. 2016;2016:6314368. doi:10.1155/2016/6314368

4. Tran F, Vu DC, Nguyen HT, et al. Glycaemic control in children with neonatal diabetes and type 1 diabetes in Vietnam. Int Health. 2011;3(3):188192. doi: $10.1016 / j$.inhe.2011.03.008

5. Rafiq M, Flanagan SE, Patch A-M, et al. Effective treatment with oral sulfonylureas in patients with diabetes due to sulfonylurea receptor 1 (SUR1) mutations. Diabetes Care. 2008; 31(2):204-209. doi:10.2337/dc07-1785

6. Cân Thị Bích Ngọc. Nghiên cứu đột biến gen, lâm sàng và điêu trị bệnh đái tháo đường sơ sinh.Luận văn tiến sỹ y học, Đại học Y Hà Nội

7. Zhang $M$, Chen $X$, Shen $S$, et al. Sulfonylurea in the treatment of neonatal diabetes mellitus children with heterogeneous genetic backgrounds. J Pediatr Endocrinol Metab. 2015;28(7-8):877-884. doi:10.1515/jpem-2014-0429

8. Flanagan SE, Mackay DJG, Greeley SAW, et al. Hypoglycaemia following diabetes remission in patients with 6q24 methylation defects expanding the clinical phenotype. Diabetologia. 2013; 56(1):218-221. doi:10.1007/s00125-012-2766-z

\title{
NGHIÊN CỨU BIẾN THIÊN NHİP TIM Ở BÊNNH NHÂN BỆNH TIM THIẾU MÁU CỤC Bộ MẠN TÍNH CÓ SUY TIM
}

\author{
Đoàn Thịnh Trường ${ }^{1,2}$, Nguyễn Oanh $\operatorname{Oanh}^{2}$, Nguyễn Quang Toàn ${ }^{3}$
}

\section{TÓM TẮT}

Đối tượng và phương pháp nghiên cứu: gồm 136 bệnh nhân bệnh tim thiếu máu cục bộ mạn tính có suy tim tại Bệnh viện Quân y 103 và Bệnh viện Tim Hà Nội từ 4 năm 2015 đến tháng 1 năm 2021. Các

\footnotetext{
${ }^{1}$ Bệnh viện Đa khoa huyện Hoài Đức

ªệnh viện Quân y 103, Học viện Quân y

${ }^{3}$ Bệnh viện trung ương Thái Nguyên

Chịu trách nhiệm chính: Đoàn Thịnh Trường

Email: bsdoanthinhtruong@gmail.com

Ngày nhận bài: 9.8.2021

Ngày phản biên khoa học: 4.10.2021

Ngày duyệt bài: 14.10.2021
}

bênh nhân tham gia nghiên cứu đáp ứng đủ các tiêu chuẩn chẩn đoán và loại trừ. Kết quả: chỉ số SDNN RMSSD, SDNNi, TP, LF, và tỷ lệ LF/HF sau điều trị (tương ứng là $62,34 \pm 32,16 ; 25,14 \pm 6,10 ; 44,45 \pm$ 13,$48 ; 1956,23 \pm 613,64 ; 1413,94 \pm 174,33 ; 3,03 \pm$ 0,71 ) đều tăng hơn so với trước điều tri (tương ứng là $38,63 \pm 18,2 ; 12,61 \pm 5,39 ; 22,66 \pm 11,47 ; 1347,92 \pm$ $412,53 ; 874,15 \pm 210,32 ; 2,21 \pm 0,68)$ với $p<0,05$. Số nhánh tổn thương càng nhiều các chỉ số biến thiên nhịp tim càng thấp. Giá tri SDNN, SDNNi, TP, HF, LF giảm dần theo số nhánh tổn thương động mạch vành, sư khác biêt có ý nghĩa với $p<0,05$. Nồng đô NTproBNP của bệnh nhân có biến thiên nhịp tim bình thường thấp hớn so với những bệnh nhẩn có giảm biến thiên nhịp tim, $p<0,05$. Kết luận: Các chỉ số 
biến thiên nhịp tim SDNN, RMSSD, SDNNi, LF và tỷ lệ LF/HF sau điều trị tăng hơn so với trước điều trị ở bệnh nhân bệnh tim thiếu máu cục bộ mạn tính có suy tim.

Tư khóa: biến thiêp nhịp tim, bệnh tim thiếu máu cục bộ mạn tính.

\section{SUMMARY}

\section{RESEARCH OF HEART RATE VARIABILITY IN CHRONIC ISCHEMIC HEART DISEASE WITH HEART FAILURE}

Subjects and methods: 136 patients with chronic ischemic heart disease with heart failure at Military Hospital 103 and Hanoi Heart Hospital from April 2015 to January 2021. The study met the diagnostic and exclusion criteria. Results: SDNN, RMSSD, SDNNi, TP, LF, and the ratio LF/HF index after treatment (respectively, $62.34 \pm 32.16 ; 25.14 \pm 6.10$; $44.45 \pm 13.48 ; 1956.23 \pm 613.64 ; 1413.94 \pm 174.33$; $3.03 \pm 0.71)$ increased more than before treatment (respectively $38.63 \pm 18.2 ; 12.61 \pm 5.39 ; 22.66 \pm$ $11.47 ; 1347.92 \pm 412.53 ; 874.15 \pm 210.32 ; 2.21 \pm$ 0.68 ) with $p<0.05$. The higher the number of damaged branches, the lower the heart rate variability index. The values of SDNN, SDNNi, TP, HF, LF gradually decreased with the number of coronary artery lesions, the difference was significant with $p<0.05$. NT-proBNP levels of patients with normal heart rate variability were lower than those of patients with reduced heart rate variability, $p<0.05$. Conclusion: Heart rate variability indices SDNN, RMSSD, SDNNi, LF and the ratio LF/HR after treatment increased more than before treatment in patients with chronic ischemic heart disease with heart failure.

Keywords; heart rate variability, chronic ischemic heart disease.

\section{I. ĐĂT VẤN ĐỀ}

Những biến cố tim mạch chẳng hạn như rối loạn nhịp đe dọa tính mạng và biến cố mạch vành cấp tính, đã được biết đến là do sự kích hoạt của hệ thống thẩn kinh tự động ở những bệnh nhân bị bệnh mạch vành. Phân tích biến thiên nhịp tim theo thời gian và theo phổ tần số đã cung cấp một phương pháp mới để nghiên cứu sự bất thường của hệ thần kinh tự động trong bệnh tim thiếu máu cục bộ.

Giảm các chỉ số biến thiên nhịp tim dự báo gia tăng nguy cơ tử vong và các biến cố tim mạch ở bệnh nhân có bệnh tim thiếu máu cục bộ. Đặc biệt, các nghiên cứu gần đây chỉ ra rằng các phương pháp phân tích biến thiên nhịp tim dự đoán tử vong và sự khởi đầu của rối loạn nhịp tim đe dọa tính mạng trong các bệnh nhẩn sau nhồi máu. Những phát hiện này ủng hộ quan điểm rằng các phương pháp phân tích biến thiên nhịp tim cung cấp thông tin có giá trị lâm sàng ở bệnh nhân có bệnh tim thiếu máu cục bộ [1].

Holter điện tim là một kỹ thuật không xâm lấn, theo dõi điện tim liên tục cả khi nghỉ và khi hoạt động, nhằm phát hiện những bất thường trên điện tim như rối loạn nhịp trên thất, rối loạn nhịp thất, biến đổi khoảng QT, điện thế chậm, biển thiên nhịp tim. Từ đó sẽ giúp điều trị và dự phòng tốt hơn cho người bị bệnh tim thiếu máu cục bộ mạn tính để tránh các biến chứng đặc biệt là đột tử. Chính vì vậy, chúng tôi tiến hành nghiên cứu đề tài "Nghiên cứu biến thiên nhịp tim ở bệnh nhân bênh tim thiếu máu cuc bộ mạn tính có suy tim" "với mục tiêu: Tim hiểu mối liên quan giữa biến thiên nhip tim với một số đặc điểm lâm sàng ở bênh nhân bệnh tim thiêu máu cục bộ mạn tính có suy tim trước và sau điều trị 7 ngày.

\section{II. ĐỐI TƯỢNG VÀ PHƯƠNG PHÁP NGHIÊN CỨU}

2.1. Đối tượng nghiên cứu. Đối tượng nghiên cứu gồm 136 người được chẩn đoán xác định BTTMCB mạn tính có suy tim điêu trị tại Bệnh viện Quân Y 103 Bệnh viện Tim Hà Nội, trong thời gian từ tháng 4 năm 2015 đến tháng 1 năm 2021.

2.1.1. Tiêu chuẩn lựa chọn. Người bệnh được chẩn đoán xác định BTTMCB mạn tính, theo "Khuyến cáo của Hội Tim mạch học Việt Nam 2008" [2].

- Lâm sàng: bệnh nhân đau ngực kiểu động mạch vành, có các yếu tố nguy cơ tim mạch.

- Cận lâm sàng: làm các test chẩn đoán bệnh ĐMV (ECG 12 đạo trình, siêu âm tim, nghiệm pháp gắng sức, MSCT ĐMV, chụp ĐMV qua da) dương tính.

\subsubsection{Tiêu chuẩn loại trừ}

- Hội chứng ĐMV cấp, suy tim cấp, bệnh lý van tim thực thể, bệnh lý cơ tim, bệnh tim bẩm sinh.

- Suy chức nẳng gan, thận, có tình trạng thiếu máu, nhiễm trùng.

- Người bệnh và gia đình không đồng ý tham gia nghiên cứu.

\subsection{Phương pháp nghiên cứu}

2.2.1. Thiết kế nghiên cứu. Nghiên cứu tiến cứu, mô tả, cắt ngang có so sánh trước sau điều trị.

2.2.2. Phương pháp chọn mẫu. Lấy mẫu thuận tiện theo trình tự thời gian, không phân biệt tuổi giới gồm 136 NB được chẩn đoán BTTMCB mạn tính có suy tim điều trị tại khoa Tim mạch, Bệnh viện Quân Y 103 và khoa Nội, Bệnh viện Tim Hà Nồi.

\subsubsection{Các chỉ tiêu nghiên cứu}

- Tuổi, giới, các chỉ số lâm sàng, cận lâm sàng.

- Các chỉ số biến thiên theo thời gian (đơn vị mili giây):

SDNN: Độ lệch chuẩn của tất cả các thời 
khoảng R-R bình thường trên toàn bộ Holter điện tim 24 giờ. Giảm khi SDNN < 50ms, phản ánh mất nhịp sinh học, giảm tác động của hệ TKTC lên nhịp tim.

. SDANN: Độ lệch chuẩn của số trung bình của tất cả các thời khoảng R-R bình thường trên toàn bộ các đoạn 5 phút của Holter điện tim 24 giờ.

. rMSSD: Căn bậc hai số trung bình của bình phương sự khác biệt giữ các thời khoảng R-R bình thường kề nhau của Holter điện tim 24 giờ. Giá trị này phản ánh chức năng TKPGC. Giảm khi rMSSD < 15ms.

. SDNNi: Trung bình của độ lệch chuẩn của tất cả các thời khoảng $R-R$ bình thường trên toàn bộ các đoạn 5 phút của Holter điện tim 24 giờ. Giảm khi SDNNi < 30ms.

- Các chỉ số phân tích phổ tân số (đơn vị ms²)

. TP: Tổng độ lớn của biến thiên nhịp tim theo phổ tân số, từ 0-0,4Hz.

. LF: Vùng tân số thấp $(0,04-0,15 \mathrm{~Hz})$, khi tăng LF thường tăng hoạt động của thân kinh giao cảm.

. HF: Vùng tân số cao $(0,15-0,40 \mathrm{~Hz})$, khi tăng HF thường tăng hoạt động của thân kinh phó giao cảm.

. Tỷ số LF/HF: đánh giá cân bằng hoạt động của thân kinh giao cảm và phó giao cảm.

2.3. Xử lí số liệu. Thông tin thu thập được từ bệnh án nghiên cứu sẽ được xử lý theo các thuật toán thống kê y học của phân mềm EPI DATA và SPSS 21.0 for Windows. $p<0,05$ trong các so sách được coi là có ý nghĩa thống kê

\section{KẾT QUẢ NGHIÊN CứU}

Bảng 3.1. Đăc điểm chung của đôi tượng nghiên cứu $(n=136)$

\begin{tabular}{|c|c|}
\hline Đăc điếm & Giá trị \\
\hline Giới nam, n (\%) & $102(75 \%)$ \\
\hline Tuối trung bình, $((X \pm S D))$ & $70,0 \pm 10,4$ \\
\hline Tăng huyết áp, n (\%) & $105(77,2)$ \\
\hline Đái tháo đường type $2, \mathrm{n}(\%)$ & $41(30,1)$ \\
\hline Đau ngực trái, n (\%) & $118(86,8)$ \\
\hline Phù, n (\%) & $19(3,7)$ \\
\hline Gan to, n (\%) & $5(3,7)$ \\
\hline Nhịp tim khi nhập viện $(X \pm S D)$ & $88,4 \pm 25,2$ \\
\hline Huyết áp tâm thu, $(X \pm S D)$ & $135,1 \pm 25,5$ \\
\hline $\begin{array}{l}\text { Nồng độ NT-proBNP trước } \\
\text { điều trị }(\mathrm{pg} / \mathrm{ml}),\left(X_{ \pm} \mathrm{SD}\right)\end{array}$ & $\begin{array}{l}2540,84 \pm \\
5486,73\end{array}$ \\
\hline $\begin{array}{l}\text { Nồng độ NT-proBNP sau điều trị } \\
(\mathrm{pg} / \mathrm{ml}),\left(X_{ \pm} \mathrm{SD}\right)\end{array}$ & $\begin{array}{c}1162,26 \pm \\
2085,61\end{array}$ \\
\hline
\end{tabular}

Nhânn xét; Giá trị nông độ NT-proBNP huyết tương sau điêu trị giảm so với trước điêu trị có ý nghĩa.

Bảng 3.2. Biến đổi các chỉ số biến thiên nhịp tim trên Holter ĐTĐ trước và sau điều trị $(n=136)$

\begin{tabular}{|c|c|c|c|}
\hline Chỉ số biến thiên nhịp tim & Trước điêu trị & Sau điêu trị & p \\
\hline SDNN $(\mathrm{ms})(X \pm \mathrm{SD})$ & $38,63 \pm 18,2$ & $62,34 \pm 32,16$ & $<0,05$ \\
\hline $\mathrm{RMSSD}(\mathrm{ms})(X \pm \mathrm{SD})$ & $12,61 \pm 5,39$ & $25,14 \pm 6,10$ & $<0,05$ \\
\hline $\mathrm{SDNNi}(\mathrm{ms})(X \pm \mathrm{SD})$ & $22,66 \pm 11,47$ & $44,45 \pm 13,48$ & $<0,05$ \\
\hline $\mathrm{TP}\left(\mathrm{ms}^{2}\right)(\bar{X} \pm \mathrm{SD})$ & $1347,92 \pm 412,53$ & $1956,23 \pm 613,64$ & $<0,05$ \\
\hline $\mathrm{HF}\left(\mathrm{ms}^{2}\right)(X \pm \mathrm{SD})$ & $400,57 \pm 182,12$ & $485,33 \pm 135,66$ & $>0,05$ \\
\hline $\mathrm{LF}\left(\mathrm{ms}^{2}\right)(X \pm \mathrm{SD})$ & $874,15 \pm 210,32$ & $1413,94 \pm 174,33$ & $<0,05$ \\
\hline $\mathrm{LF} / \mathrm{HF}(X \pm \mathrm{SD})$ & $2,21 \pm 0,68$ & $3,03 \pm 0,71$ & $<0,05$ \\
\hline
\end{tabular}

Nhận xét: Các chỉ số biến thiên nhịp tim SDNN, TP, LF và tỷ lệ LF/HF tăng ở bệnh nhân bệnh tim thiếu máu cục bộ mạn tính có suy tim sau điều trị, sự khác biệt có ý nghĩ thông kê $(p<0,05)$.

Bảng 3.3. Biên đổi về chỉ số biến thiên nhịp tim trên Holter ĐTĐ với số thân động mạch vành tổn thương

\begin{tabular}{|c|c|c|c|c|}
\hline \multirow{2}{*}{ Chỉ số } & $\begin{array}{c}\text { Một thân } \\
(\mathbf{n}=\mathbf{7 5})\end{array}$ & $\begin{array}{c}\text { Hai thân } \\
(\mathbf{n}=\mathbf{2 8})\end{array}$ & $\begin{array}{c}\text { Ba thân } \\
(\mathbf{n}=\mathbf{3 3})\end{array}$ & \multirow{2}{*}{$\mathbf{p}$} \\
\cline { 2 - 5 } & $(\overline{\boldsymbol{X}} \pm \mathrm{SD})$ & $(\overline{\boldsymbol{X}} \pm \mathrm{SD})$ & $(\overline{\boldsymbol{X}} \pm \mathrm{SD})$ & \\
\hline SDNN $(\mathrm{ms})$ & $56,46 \pm 28,59$ & $35,22 \pm 20,09$ & $20,46 \pm 16,55$ & $<0,05$ \\
\hline RMSSD (ms) & $23,27 \pm 7,35$ & $20,12 \pm 7,44$ & $16,97 \pm 5,62$ & $<0,05$ \\
\hline SDNNi (ms) & $38,33 \pm 12,72$ & $31,31 \pm 13,23$ & $20,95 \pm 9,64$ & $<0,05$ \\
\hline $\mathrm{TP}\left(\mathrm{ms}^{2}\right)$ & $1947,45 \pm 410,09$ & $1476,34 \pm 344,29$ & $1069,69 \pm 304,54$ & $<0,05$ \\
\hline $\mathrm{HF}\left(\mathrm{ms}^{2}\right)$ & $439,53 \pm 169,66$ & $247,58 \pm 112,43$ & $60,18 \pm 68,48$ & $<0,05$ \\
\hline $\mathrm{LF}\left(\mathrm{ms}^{2}\right)$ & $722,34 \pm 234,49$ & $465,38 \pm 168,75$ & $211,37 \pm 124,27$ & $<0,05$ \\
\hline $\mathrm{LF} / \mathrm{HF}$ & $2,63 \pm 0,59$ & $3,21 \pm 0,6$ & $3,56 \pm 0,64$ & $<0,05$ \\
\hline
\end{tabular}

Nhận xét: Có sự liên quan giữa mức độ tổn thương động mạch vành ở bệnh nhân bệnh tim thiếu máu cục bộ mạn tính với biến thiên nhịp tịm. Số thân động mạch vành tổn thương càng nhiều thì các chỉ số biến thiền càng thấp, sự khác biệt có ý nghĩa thống kê $(p<0,05)$. 
Bảng 3.4. Biến đổi về chỉ số biên thiên nhịp tim trên Holter ĐTĐ theo phân suât tống máu thất trái

\begin{tabular}{|c|c|c|c|}
\hline Chỉ số biến thiên nhịp tim & $E F \geq 50 \%(n=86)$ & $E F<50 \%(n=50)$ & p \\
\hline SDNN (ms), $(X \pm$ SD $)$ & $41,23 \pm 20,03$ & $35,13 \pm 25,65$ & $<0,05$ \\
\hline $\operatorname{RMSSD}(\mathrm{ms}),(\underline{X} \pm \mathrm{SD})$ & $14,35 \pm 6,30$ & $13,38 \pm 6,65$ & $<0,05$ \\
\hline SDNNi $(\mathrm{ms}),(X \pm \mathrm{SD})$ & $21,67 \pm 11,25$ & $20,95 \pm 13,07$ & $>0,05$ \\
\hline $\mathrm{TP}\left(\mathrm{ms}^{2}\right),(\underline{X} \pm \mathrm{SD})$ & $1868,44 \pm 532,17$ & $1461,38 \pm 507,35$ & $<0,05$ \\
\hline $\mathrm{HF}\left(\mathrm{ms}^{2}\right),\left(\frac{X}{v} \pm \mathrm{SD}\right)$ & $313,11 \pm 75,47$ & $157,56 \pm 62,14$ & $<0,05$ \\
\hline $\mathrm{LF}\left(\mathrm{ms}^{2}\right),(X \pm \mathrm{SD})$ & $703,45 \pm 502,10$ & $311,62 \pm 423,63$ & $<0,05$ \\
\hline $\mathrm{LF} / \mathrm{HF},(X \pm \mathrm{SD})$ & $2,24 \pm 0,52$ & $1,93 \pm 0,7$ & $<0,05$ \\
\hline
\end{tabular}

Nhận xét: Các chỉ số biến thiên nhịp tim: SDNN, RMSSD, TP, HF, LF, LF/HF ở nhóm EF > 50\% và $\mathrm{EF}<50 \%$ có sự khác biệt $(\mathrm{p}<0,05)$. Chỉ số SDNNi ở nhóm $\mathrm{EF}>50 \%$ và $\mathrm{EF}<50 \%$ không có sự khác biệt $(p>0,05)$.

Bảng 3.5. Mối liên quan giữa các chỉ số giảm biến thiên nhịp tím theo thời gian với nồng độ NT-proBNP

\begin{tabular}{|c|c|c|c|c|c|}
\hline \multicolumn{2}{|c|}{ Chỉ số biến thiên nhịp tim } & \multicolumn{2}{|c|}{$\begin{array}{c}\text { NT-proBNP } \\
\text { trước điêuu trị }(\mathrm{pg} / \mathrm{ml})\end{array}$} & \multicolumn{2}{|c|}{$\begin{array}{c}\text { NT-proBNP } \\
\text { sau điêu trị }(\mathrm{pg} / \mathrm{ml})\end{array}$} \\
\hline \multirow{2}{*}{$\begin{array}{l}\text { SDNN } \\
(\mathrm{ms})\end{array}$} & $m c(n-40)$ & $2480,37 \pm 5546,48$ & \multirow{2}{*}{$p<0,05$} & $1082,16 \pm 2165,62$ & \multirow{2}{*}{$p<0,05$} \\
\hline & $\geq$ & $00 \pm 669,5$ & & $592,99 \pm$ & \\
\hline \multirow{2}{*}{$\begin{array}{l}\text { RMSSD } \\
(\mathrm{ms})\end{array}$} & IS $(n=44)$ & 5,54 & \multirow{2}{*}{$p<0,05$} & 116 & \multirow{2}{*}{$p<0,05$} \\
\hline & $<3$ & $2468,45 \pm 5307,84$ & & $1265,61 \pm 2162,8$ & \\
\hline $\begin{array}{l}\text { SDNNi } \\
\text { (ms) }\end{array}$ & $\geq 30 \mathrm{~ms}(\mathrm{n}=102)$ & $950,96 \pm 600,78$ & $p<0,05$ & $589,86 \pm 499,92$ & $p<0,05$ \\
\hline
\end{tabular}

Nhận xét: Nồng độ NT-proBNP của bệnh nhân có biến thiên nhịp tim bình thường (SDNN $\geq$ $50 \mathrm{~ms}$, RMSSD $\geq 15 \mathrm{~ms}$, SDNNi $\geq 30 \mathrm{~ms}$ ) thấp hơn so với những bệnh nhân có giảm biến thiên nhịp tim (SDNN < 50ms, RMSSD $<15 \mathrm{~ms}$, SDNNi < 30ms), p < 0,05.

\section{BÀN LUÂ̂N}

Một số nghiên cứu cho thấy các chỉ số biễn thiên nhịp tim ở người suy tim giảm hơn người bình thường và giảm theo mức độ suy tim, sau điêu trị các chỉ số này có cải thiện. Kết quả bảng 3.2 của chúng tôi cũng cho thấy điêuu đó với chỉ số SDNN, RMSSD, SDNNi, TP, LF, và tỷ lệ LF/HF sau điêu trị (tương ứng là 62,34 $\pm 32,16 ; 25,14 \pm$ 6,$10 ; 44,45 \pm 13,48 ; 1956,23 \pm 613,64 ; 1413,94$ $\pm 174,33 ; 3,03 \pm 0,71)$ đều tăng hơn so với trước điều trị (tương ứng là $38,63 \pm 18,2 ; 12,61 \pm$ 5,$39 ; 22,66 \pm 11,47 ; 1347,92 \pm 412,53 ; 874,15 \pm$ $210,32 ; 2,21 \pm 0,68)$ với $p<0,05$.

Kết quả bảng 3.3 cho thây sự liên quan các chỉ số biến thiên nhịp tim với số nhánh ĐMV bị tổn thương. Số nhánh tổn thương càng nhiêu các chỉ số biến thiên nhịp tim càng thấp. Giá trị SDNN, SDNNi, TP, HF, LF giảm dần theo sổ nhánh tổn thương (một nhánh là $56,46 \pm 28,59$; $38,33 \pm 12,72 ; 1947,45 \pm 410,09 ; 439,53 \pm$ 169,$66 ; 722,34 \pm 234,49$, hai nhánh lần lượt là $35,22 \pm 20,09 ; 31,31 \pm 13,23 ; 1476,34 \pm 344,29$; $247,58 \pm 112,43 ; 465,38 \pm 168,75$ và ba nhánh lần lượt là $20,46 \pm 16,55 ; 20,95 \pm 9,64 ; 1069,69$ $\pm 304,54 ; 60,18 \pm 68,48 ; 211,37 \pm 124,27$ ), sự khác biêtt có ý nghĩa với $\mathrm{p}<0,05$.

Nghiên cứu của tác giả Lê Thị Ngọc Hân về biến thiên nhịp tim ở bệnh nhân bệnh tim thiếu máu cục bộ mạn tính, kết quả cho thây các chỉ số biến thiên nhịp tim SDNNi, RMSSD, TP, HF, LF thấp hơn trong 24 giờ đầu sau khi được can thiệp động mạch vành qua da sự khác biệt là có ý nghĩa với $\mathrm{p}<0,05$ [3]. Tác giả lý giải rẳng: sự giảm các thông số biến thiên nhịp tim trong giai đoạn đầu sau can thiệp tái thồng động mạch vành có thể là tam thời và có thể liên quan tới chấn thương nội mạc trong quá trình làm thủ thuật hoặc thuyên tắc ở các vi mạch. Tái tưới máu gây chấn thương nội mạc do khi lưu lượng mạch vành tăng gây ra tình trạng quá tải áp lực và tăng sức căng các sợi cơ tịm dẫn đến phù nề, co thắt, thậm chí chết tế bào. Đồng thời, sau tái thông động mạch vành diễn ra những thay đổi về mặt chuyển hóa như tăng nồng độ kali, nồng độ adenosin, nhiễm toan, giải phóng các gốc tự do, quá tải canxi trong ty lạp thể và rối loạn chức năng nội mạc. Những hiện tượng này có thể gây mất chi phối thần kinh của các tận cùng thần kinh tim, đầu tiên là ở lớp nội mạc cơ tim (nơi có các tận cùng thần kinh phó giao cảm), sau đó là vùng ngoại mạc cơ tim, dẫn đến giảm hoạt động của hệ thần kinh tự động biểu hiện thông qua giảm các thông số biến thiên nhịp tim. Tác giả cũng nhấn mạnh rằng các biến đổi của BTNT 24 sau can thiệp chỉ mang tính tạm thời và sẽ cải thiện theo thời gian. Nhiều tác giả khác cũng đã 
quan sát thấy sự cải thiện hầu hết các thông số biến thiên nhịp tim sau 1 tháng, 3 tháng và 1 năm sau can thiệp động mach vành. Li H.R. và cộng sự, nghiên cứu 514 bệnh nhân (tuổi trung bình $66,1 \pm 14,3$ ), holter điện tim được thực hiện trước khi chụp động mạch vành và biến thiên nhịp tim trong 24 giờ được phân tích trong cả miền tần số (LF, HF và $T P$ ) và miền thời gian (SDNN, SDNNi, RMSSD), kết quả có 203 bệnh nhân $(39,6 \%)$ có tổn thương ĐMV, các bệnh nhân mắc bệnh ĐMV có biến thiên nhịp tim thấp hơn theo cả thông số miền tần số và thời gian. Sau khi kiểm soát tuổi, giới, nhịp tim, huyết áp tâm thu, chức năng thận, rối loạn lipid máu thì các chỉ số biến thiên nhịp tim giảm vẩn là các yếu tố dự báo bệnh mạch vành $(\mathrm{OR}, 95 \% \mathrm{CI}$ cho $\mathrm{LF}, \mathrm{HF}, \mathrm{SDNN}, \mathrm{RMSSD}$ và pNN20: $0,81,0,66-$ 0,$99 ; 0,77,0,63-0,94 ; 0,75,0,59-0,96 ; 0,72$, $0,58-0,88$; và $0,76,0,62-0,94)$. Biến đổi nhịp tim (HRV) thường giảm ở bệnh nhân bệnh ĐMV ổn định, HRV giảm là yếu tố dự đoán tổn thương đông mạch vành ở bệnh nhân BTTMCB mạn tính [4]. Giảm biến thiên nhịp tim phản ánh sự mất cân bằng của hệ thần kinh tự chủ, chủ yếu là sự giảm hoạt tính của hê thần kinh phó giao cảm ở bệnh nhẩn tổn thương nhiều thân hệ mạch vành [5], [6]. Trần Thái Hà, nghiên cứu với 169 bệnh nhân bị BĐMV mạn tính sau nhồi máu cơ tim cấp 12 tháng được điều trị và theo dõi tại Bệnh viện trung ương Quân đội 108 từ tháng 5 năm 2004 đến tháng 12 năm 2010 và nhóm chứng là 72 người bình thường, kết quả cho thấy các chỉ số biến thiên nhịp tim SDNN, RMSSD, SDNNi, TP, HF thấp và $L F$, LF/HF tăng hơn sau nhồi máu cơ tim cấp và sau theo dõi đến 12 tháng so với nhóm chứng (với $\mathrm{p}<0,05$ ); các chỉ số biến thiên nhịp tim SDNN, RMSSD, SDNNi, TP, HF cũng thấp hơn và $L F, L F / H F$ cũng tăng hơn ở nhóm có ngoại tâm thu thất so với nhóm không có ngoại tâm thu thất (với $\mathrm{p}<0,05$ ).

Phân tích biến thiên nhịp tim ở những bệnh nhân suy tim BTTMCB mạn tính có phân xuất tống máu thất trái giảm cho thấy chỉ số SDNN, RMSSD, TP, HF, LF và LF/HF là cao hơn ở nhóm có $\mathrm{EF} \geq 50 \%$ so với nhóm có $\mathrm{EF}<50 \%$, sự khác biệt là có ý nghĩa thống kê với $p<0,05$. Kết quả nghiên cứu của Heikki R. và cộng sự cho thây, chỉ số LnSDNN, LN HF giảm và LnVLF, LnLF tăng ở 312 bệnh nhân có giảm chức năng tâm thu thất trái so với nhóm có chức năng thất trái bình thường [7]. Như vậy có thể thấy phân suất tống máu có liên quan chặt chẽ với các chỉ số biến thiên nhịp tim.

Trong nghiên cứu của chúng tôi, các chỉ số biến thiên nhịp tim theo miền thời gian (SDNN, RMSS) ở nhóm bênh nhân có bệnh tim thiếu máu cục bộ mạn tính suy tim có chức năng tâm thu thất trái bảo tồn sư tăng lên có ý nghĩa so với nhóm bệnh nhân có chức năng tâm thu thất trái giảm $(41,23 \pm 20,03$ và $14,35 \pm 6,30$ so với $35,13 \pm 25,65 ; 13,38 \pm 6,65)$, sự khác biẹt là có ý nghĩa với $p<0,05$. Tương tự, các chỉ số biến thiên theo miền tần số (TP, $\mathrm{HF}, \mathrm{LF}$ ) trên các bệnh nhân có bệnh tim thiếu máu cục bộ mạn tính suy tim có chức năng tâm thu thất trái bảo tồn tăng lên có ý nghĩa so với các bệnh nhân có chức năng tâm thu thất trái giảm trong nghiên cứu này (bảng 3.4). Điều này cho thây sự tăng trương lực hoat đông của hê thống thần kinh giao cảm so với hệ thần kinh phó giao cảm ở những bệnh nhân bệnh tim thiếu màu cục bộ man tính có suy tim với phân xuất tống màu thẩt trái giảm.

Khi tìm hiểu mối liên quan giữa các chỉ số giảm biến thiên nhịp tim theo thời gian với nồng độ NT-proBNP, chúng tôi nhận thấy: nồng độ NT-proBNP của bệnh nhân có biến thiên nhịp tịm bình thường (SDNN $\geq 50 \mathrm{~ms}$, RMSSD $\geq 15 \mathrm{~ms}$, SDNNi $\geq 30 \mathrm{~ms}$ ) thấp hơn so với những bênh nhân có giảm biến thiên nhịp tim (SDNN < $50 \mathrm{~ms}$, RMSSD < 15ms, SDNNi < 30ms), $\mathrm{p}<0,05$ (bảng 3.5). Anand và cộng sự (2020) khi nghiên cứu về NT-ProBNP và biến thiên nhịp tim ở bênh nhân suy tim phân suất tống máu giảm (EF $\leq$ 40\%) theo dõi trong thời gian 6 tháng nhận thấy nhịp tim, biến thiên nhịp tim (SDNN), khoảng cách đi bộ 6 phút và NYHA được cải thiện đáng kể, không phụ thuộc vào NT-proBNP ban đầu [8]. Stancheva và cộng sự khi nghiên cứu về giá trị tiên lương của NT-proB̉NP trước khi xuất viện và biến thiên nhịp tim ở những bênh nhân suy tim phân suất tống máu giảm so với những bệnh nhân suy tim phân suất tống máu bảo tồn nhận thấy nồng độ NT-proBNP có liên quan đến tiển lượng xấu ở bệnh nhân suy tim không phân biệt chức năng tâm thu trong khi biến thiên nhịp tim chỉ phản ánh mức độ nghiêm trọng và tiên lượng xấu của suy tim có phân suất tống máu giảm[9]. Nghiên cứu của Kosheleva và cộng sự (2012) ở các bệnh nhân suy tim mạn tính thấy rằng thành phần tần số thấp (LF) của biến thiên nhip tim theo phổ tần số có liên quan tỷ lê nghịch với NTproBNP và phân số tống máu thất trái, đồng thời LF $<5,2 \ln$ ms là một yếu tố nguy cơ độc lập của suy tim mạn tính mất bù, nhồi máu cơ tim tái phát và kết cục gây tử vong.

\section{KẾT LUÂ̂N}

Các chỉ số biến thiên nhịp tim SDNN, RMSSD, 
SDNNi, LF và tỷ lệ LF/HF sau điêu trị tăng hơn so với trước điều trị ở bệnh nhân bệnh tim thiếu máu cục bộ mạn tính có suy tim.

\section{TÀI LIÊU THAM KHẢO}

1. Heikki V., Huikuri.,Timo H., et al. (2001). Heart rate variability in ischemic heart disease. autonomicneuroscience., 90 (1-2): 95-101.

2. Phạm Gia Khải và cộng sự. (2008). Khuyến cáo 2008 của Hô̂i Tim mach học Viêt Nam về bênh động mạch vành mạn tính. Khuyến cáo về các bệnh lý tim mạch và chuyển hóa. Nhà xuất bản $Y$ hoc:329-351.

3. Lề Thị Ngọc Hân và cộng sự. (2015). Nghiên cứu biến thiên nhip trên trên Holter điên tim 24 giờ ở bệnh nhân bệnh tim thiếu máu cục bộ mạn tính. J 108 Clin Med Pharm., 10 (6): 41-45.

4. Li H.R., Tse-Min Lu., Hao-Min Cheng., et al. (2016). Additive Value of Heart Rate Variability in Predicting Obstructive Coronary Artery Disease Beyond Framingham Risk. Circulation., 80: 494-501.

5. Akselrod S., Gordon D., Ubel F.A., et al.
(1981). Power spectrum analysis of heart rate fluctuation: a quantitative probe of beat-to-beat cardiovascular control. Science., 213 (4504): 220-222.

6. Björkander I.C., Forslund L.A., Kahan T.C., et al. (2008). Differential Index: A Simple Time Domain Heart Rate Variability Analysis with Prognostic Implications in Stable Angina. Cardiology., 111: 126-133.

7. Heikki R., Esa H., Niilo K., et al. (2009). Heart rate variability and stress hormones in novice and experienced parachutists anticipating a jump. Aviat Space Environ Med., 80 (11): 976-980.

8. Anand I., Ardell J. L., Gregory D., et al. (2020). Baseline NT-proBNP and responsiveness to autonomic regulation therapy in patients with heart failure and reduced ejection fraction. Int J Cardiol Heart Vasc., 29: 100520.

9. Stancheva N., Tisheva S., Jordanova V., et al. (2008). NT ProBNP and HRV and outcome in patients with heart failure with reduced vs. preserved systolic function. Journal of IMAB Annual Proceeding (Scientific Papers), 14: 89 - 94.

\section{ĐÁNH GIÁ KẾT QUẢ XA TRI TOÀN NÃO ĐIỀU TRỊ CÁC TỔN THƯƠNG UNG THƯ PHỔI KHÔNG TẾ BÀO NHỎ DI CĂN NÃO}

\section{TÓM TẮT}

Ung thư phổi (UTP) là một trong 3 ung thư thường gặp nhất và là nguyên nhân gây tử vong hàng đâu do ung thư trên phạm vi toàn cầu. UTP gồm 2 loại chính là UTP tế bào nhỏ (UTPTBN) và UTP không tế bào nhỏ (UTPKTBN). UTP giai đoạn tiến triển thường là di căn não. Đã có nhiêu thử nghiêm lâm sàng khác nhau đánh giá hiệu quả xạ trị toàn não đơn thuần trong điêu trị UTP di căn nã̃o và so sánh hiệu quả với các phương pháp điều trị khác. Kết quả đã chỉ ra rằng xạ trị toàn não đớn thuần giúp kiểm soát nhanh chóng và̀ giảm nhẹ các triệu chứng chèn ép thần kinh, nâng cao chất lượing sống cho bệnh nhân (BN). Đối tượng và phương pháp: 32 BN UTPKTBN di căn não 1-3 ổ, đường kính lớn nhất $\leq 30 \mathrm{~mm}$, được xạ trị toàn não 30 Gy với phân liều 3Gy/ngày, 5 ngày/tuần. Đánh giá kết quả sau xạ trị. Kết quả: Xạ trị toàn não đơn thuần làm biến mất tổn thương di cẳn não $6,2 \%$, giảm kích thước ổ di căn $(53,2 \%)$, kiểm soát ổ di căn ở $96,9 \%$ $\mathrm{BN}$. Xạ trị toàn não đơn thuần giúp cải thiện chỉ số PS ở 84,4\%; tỷ lệ BN có giảm các triệu chứng cơ năng chiếm $62,5 \%$, trong đó có $12,5 \%$ BN hết hoàn toàn triệu chứng. Kết luận: Xạ trị toàn não đơn thuần giúp

\section{${ }^{1}$ Bênh viên $K$}

Chịu trách nhiệm chính: Đồng Văn Hưởng

Email: dongnhangiabao@gmail.com

Ngày nhận bài: 3.8.2021

Ngày phản biên khoa học: 4.10 .2021

Ngày duyệt bài: 12.10.2021
Đồng Văn Hưởng ${ }^{1}$, Đinh Công Định' ${ }^{1}$, Nguyễn Văn Long1, Nguyễn Lan Phương1

kiểm soát nhanh chóng và giảm nhẹ triệu chứng chèn ép thần kinh nội sọ, giúp nâng cao chất lượng sống cho BN.

\section{SUMMARY \\ EVALUATING THE RESULTS OF WHOLE \\ BRAIN RADIOTHERAPY OF NSCLC'S BRAIN METASTATIC LESSIONS}

Lung cancer is one of three most common cancer disease and also is main cause of mortality worldwide. It includes two main types, one is small cell lung cancer (SCLC) and the other is non-small cell lung cancer (NSCLC). Advanced stage-lung cancer normally develops brain metastasis. There have been many different clinical trials to evaluate results of whole brain radiotherapy alone (WBRT Alone) in treatment of lung cancer's brain metastasis and compared with other therapies. It's shown that WBRT Alone can help to manage and to reduce the symptoms of intracranial pressure so that the patients' life-quality improved. Patients and methods: Including 32 patients NSCLC with brain metastasis. There are from one to three lesions with maximum diameter $\leq 30 \mathrm{~mm}$. WBRT Alone with 30Gy, the fraction is $3 G y /$ day and 5 days/week. The results were evaluated after radiotherapy. Results: $6,2 \%$ brain metastasis disappeared completely. The sizes of brain metastasis lesions reduces $53,2 \%$ and also $96,9 \%$ of those are controlled. After WBRT Alone was given, $84,4 \%$ of patients'PS are improved and also subjective symptoms of $62,5 \%$ of patients reduced and $12,5 \%$ of 